\title{
Internalization theory: an unfinished agenda
}

Article

Supplemental Material

Creative Commons: Attribution-Noncommercial-No Derivative Works 4.0

Formal mathematical model

Casson, M., Porter, L. and Wadeson, N. (2016) Internalization theory: an unfinished agenda. International Business Review, 25 (6). pp. 1223-1234. ISSN 0969-5931 doi:

https://doi.org/10.1016/j.ibusrev.2016.03.007 Available at https://centaur.reading.ac.uk/61847/

It is advisable to refer to the publisher's version if you intend to cite from the work. See Guidance on citing.

To link to this article DOI: http://dx.doi.org/10.1016/j.ibusrev.2016.03.007

Publisher: Elsevier

All outputs in CentAUR are protected by Intellectual Property Rights law, including copyright law. Copyright and IPR is retained by the creators or other copyright holders. Terms and conditions for use of this material are defined in the End User Agreement.

\section{www.reading.ac.uk/centaur}

\section{CentAUR}

Central Archive at the University of Reading

Reading's research outputs online 


\title{
Internalization Theory: An Unfinished Agenda
}

\section{Mark Casson, Lynda Porter and Nigel Wadeson}

\begin{abstract}
Internalization theory is usually applied at the firm level to analyse FDI, licensing and subcontracting, but this paper extends it to the industry level. It synthesises internalisation theory and oligopoly theory. It analyses a global industry where firms innovate competitively, and freely enter and exit the industry. It presents a formal model which highlights the inter-dependencies between rival firms. Each firm responds to its rivals by jointly optimising production and innovation through inter-dependent ownership and location decisions. The competitive outcome determines which firms serve which markets, which firms enter or exit the industry, and the internalisation strategy of each firm. (100 words)
\end{abstract}

Keywords: Internalization, Industry, Competition, Price, Innovation, Ownership

\section{INTRODUCTION}

'As the field of international business has continued to evolve, a proliferation of new theories, frameworks, and concepts have been developed and applied.... Whilst new insights and research streams are essential to the vitality of any field, in the case of international business it can sometimes appear as if the core theories are being forgotten or overlooked at best, and misunderstood at worst' (Rugman, 2014: 201).

This paper focuses on internalization as a core theory (Buckley and Casson, 1976; Rugman, 1981). It extends the theory from the firm level to the industry level. It analyses a global industry, populated by a diversity of firms. Firms co-operate through licensing and subcontracting arrangements, but they also compete for market share. Competition is driven by both innovation and price. Within the 
industry, competition determines the number of firms, whilst internalization determines the boundaries between them.

There are two dimensions of competition in the model: short-run local competition, in which individual firms compete to supply a local market, and long-run global competition in which firms compete to innovate technologies. Short-run competition is modelled using the economic theory of markets whilst long-run completion is modelled using the theory of non-cooperative games. The number and nature of firms, and the boundaries between them, are all endogenous. Each firm's strategy responds to other firms' strategies, but some aspects of strategy are more 'strategic' than others; innovation, R\&D location and headquarters location decisions interact more with other firms' decisions than individual market entry decisions.

Industry-level analysis is important when discussing 'industry recipes' - whether different industries are populated by different types of firm (Spender, 1989), and if so why. The question of why certain industries were more 'multinational' than others was the original spur to the development of internalization theory. Industry analysis is relevant to contemporary issues, such as whether multinationals in certain industries are more likely to be regional than global, or are more inclined to engage in out-sourcing and off-shoring. Whilst these issues can be partially addressed in terms of 'representative firms' there is no substitute for a comprehensive analysis of an industry as a whole.

Section 2 reviews the literature, focusing selectively on key issues that are addressed by the model. Section 3 motivates the model and section 4 summarises its overall structure. The model is solved using a three-stage procedure that is explained in section 5 (technical details are presented in the Appendix). Section 6 discusses applications to various industries, including automobiles, pharmaceuticals and IT; it also explains how the results clarify important issues in IB theory. Section 7 summarises the conclusions and discusses implications for future research.

\section{LITERATURE REVIEW}

The roots of internalization theory lie in the policy debates of the 1970s. A major challenge at that time was to explain why multinational enterprises (MNEs) were predominantly headquartered in the 
US, invested mainly in Europe, and were concentrated in high-technology or marketing-intensive industries (Dunning, 1958). The objective was to develop a general theory of the MNE that would explain how different patterns of international business (IB) activity would emerge at different times under different circumstances (Buckley and Casson, 2009). The theory would be expressed in terms of a formal model in which IB activity was governed by a range of factors including the level of technology, product complexity, geographical and cultural distance, intellectual property rights and political risks.

The model was to be constructed by integrating Coase's (1937) theory of the firm with standard models of international trade and economic geography (Ohlin, 1933; Weber, 1929). The IB system was regarded as a network of production facilities linked by flows of intermediate product. The ownership of these facilities was explained by internalization theory, derived from Coase, whilst their location was explained in terms of comparative advantage and trade.

Coase's original analysis of internalization focused on the industry as well as the firm. In Coase's view industry competition dictated which types of firms existed and which did not. Firms could survive only if they coordinated production more effectively than the market. Final products markets were external to the firm - these were markets where firms competed to sell to customers. Intermediate product markets were different; firms could internalise them in order to improve the coordination of production. Different firms would have different boundaries, and at these boundaries the firms would interface with each other. Where the firms traded intermediate products on a longterm basis a cooperative relationship could emerge, but in final product markets competition was almost invariably the rule. Industry level analysis explains how the boundaries of the firms mesh together within supply chains, and how different supply chains compete for market share in different national markets. It thereby provides a comprehensive analysis of the number and the nature of all the firms in an industry.

There are two main kinds of intermediate products in an industry - tangible semi-processed goods, e.g. automotive components, and intangible knowledge-based products such as technologies and brands. Knowledge-based products are protected through intellectual property rights, which are often difficult 
to enforce. The key to internalisation theory was to recognise that technological know-how was an intermediate public good, generated in a central $R \& D$ facility and shared by production facilities around the world. Market imperfections for knowledge tend to be high (e.g. the cost of licensing). Internalization of knowledge flow provided the basic rationale for the MNE, although internalization of other intermediate product flows was relevant too - e.g. global supply chains based on modular technologies..

Although the modelling agenda advanced incrementally (Buckley and Casson, 1985; 1998a; 1998b; Buckley and Hashai, 2004; Rugman, 1981), it was gradually eclipsed by conceptual controversies over internalization. The relationships of internalization theory to the 'eclectic theory' (Dunning, 1977), the resource-based theory of the firm (Barney, Wright and Ketchen, 2001; Cantwell, 2014) and theories of emerging market MNEs (Ramamurti and Singh, 2009) were all hotly debated. The interface with strategic management theory was debated by Dunning (1993) and Moon, Rugman and Verbeke (1995). Controversy developed over the nature and necessity of firm-specific ownership advantages, and even over the nature of internalization itself (Hennart, 1982). Had the modelling agenda been pursued more vigorously, some of these controversies might have been resolved more quickly.

Parallel developments in industrial economics, trade theory and economic geography (Iammarino and McCann, 2013, Krugman, 1991) have led to the development of formal models in these fields which incorporate significant elements of internalization theory (Markusen, 2002). These models are somewhat abstract and over-simplified, however, and often understate the diversity and heterogeneity of firms as demonstrated by the IB literature (Beugelsdijk and Mudambi, 2013). What is required is a synthesis of the firm-specific view that dominates contemporary IB literature and the industry-specific view that has traditionally dominated economic modelling of regions, trade and industry (Beugelsdijk, Brakman, van Ees and Garretson, 2014). This paper strives towards this objective.

The model strengthens the links between mainstream IB theory and the literature on innovation and industrial organization (IO). Competition is the key concpt that links the two - in particular, oligopolistic competiton between a small number of firms. The link to IO goes back to the international oligopoly models of Rowthorn and Hymer (1971), Vernon (1971), Knickerbocker (1973) 
and Graham (1978), whilst the link to innovation goes back to Cantwell (1989). The model follows recent literature by focusing on strategic interdependencies between innovation and FDI (Petit and Sanna-Randaccio, 2000; Petit, Sanna-Randaccio and Sestini, 2012; Sanna-Randaccio and Veugelers, 2007). It arrives at somewhat different results. Unlike the mainstream IO literature on FDI, it focuses on the sunk costs of R\&D rather than the sunk costs of individual market entry. Unlike the existing literature, it also relates sunk costs explicitly to the ownership and location of R\&D. Inter-firm strategic rivalry is therefore focused on innovation rather than on mode of market entry.

\section{DETAILED MOTIVATION FOR THE MODEL}

Much of the policy debate on globalization is expressed in terms of industries rather than firms. The IB literature provides important case studies, particularly of innovative MNEs, but these cannot claim to be representative of firms in an industry as a whole. An industry typically comprises a diverse set of competing firms whose products are substitutes for each other. They are not perfect substitutes, however, as assumed in standard economic theory; instead they are differentiated by design, technology and brand (e.g. the mobile phone industry). Their specific features are key to the success and failure of individual firms. What is required is a theory of industry rivalry in which every firm is different, and this points towards a multi-player game of the kind employed in this model.

In case study analysis the existence of the firm being studied is, naturally, taken as a given. Similarly in standard theories of oligopoly the number of firms in an industry is also taken as a given. But in practice new firm entry is an important factor - emerging market MNEs being an obvious case. The game played out at the industry level therefore involves potential entrants. Furthermore, the risk to incumbents posed by successful entrants means that potential exits must also be taken into account. An innovative industry, in other words, involves a game played out by both actual and potential firms. This feature is captured by the model.

The simplest way to develop such a model is to embed internalization within a multi-player industry game in which both actual and potential firms compete. 
IB theory emphasises intangible products because their But even where tangible products are important, knowledge remains important An industry-based internalization model includes both types of intermediate product, although the emphasis below is on knowledge.

Proprietary knowledge is costly to develop. Because knowledge can be shared, a substantial component of cost is fixed independently of its use. Cost is also sunk, e.g. it cannot be recovered if a newly-developed product is not brought to market. In the present model technologies are developed in $R \& D$ facilities owned by rival firms. Each firm must take an innovation decision - whether to commit to sunk costs. If they commit they will wish their product to serve as wide a market as possible in order to spread their fixed costs. Competition between the innovators then 'kicks in'. The more firms that innovate the more firms will attempt to enter each national market and the stronger local competition will be; the stronger the competition, the lower will be product price; the lower the price, the more difficult it is for firms to earn a profit; and the lower the profit, the more difficult it is, even with a potential global market, for a firm to cover the fixed costs of R\&D. Each firm's innovation decision therefore poses a threat to rival firms. It is not just the number of firms that innovate that matters to each firm, but which particular firms decide to do so. Two firms that develop very similar technologies, or develop them at a nearby locations, pose more serious competition for each other than firms that develop rather different technologies at distant locations. With diverse firms, each firm needs to identify its rivals individually and to predict their entry decisions. A model based on a multiplayer game can analyse these strategic interdependencies in a rigorous way.

Successful innovation depends, like everything else, on the relationship between costs and prices. Internalization and location decisions are important in reducing the costs of serving individual markets. Indeed, much of conventional IB theory is concerned with optimising individual market entry decisions. The literature, however, confines itself mainly to the familiar choice between exporting, licensing and FDI. The industry model takes a different approach, by evaluating every possible permutation of internalization and location strategies for each technology, including the off-shoring of production and $R \& D$. This illustrates another benefit of taking an industry view: namely, that many 
implicit assumptions traditionally made in analysing market sourcing can be relaxed by taking a wider view.

Within the model internalization and location decisions are cost-driven. Each firm serves each market using the cheapest possible mode. But not every firm necessarily serves each market. Each firm is constrained, not only by the customers' overall willingness to pay, but by rival innovators that quote lower prices. Once a technology has been developed, it only pays a firm to serve a given market if the price they can obtain from that market equals or exceeds their unit cost of supply. Each firm has a different unit cost of supply to each market, reflecting the cost of serving that market from wherever its production is located and from wherever its headquarters and R\&D are based. Geographical, cultural and institutional distances all have their part to play in determining the unit cost of supply. Price differentials between local markets are sustainable provided that independent re-sellers cannot arbitrage between them.

Without a theory of price, it is almost impossible to address fully the profitability of the firm. An industry model determines profits as well as price. The model explains which firms enter which markets, what prices they obtain, what costs they incur using their optimal supply chain strategy, and hence, by comparing costs and prices, it determines how much profit each firm makes from each market. Aggregating profits over all markets determines how much profit each firm earns in total. This profit can then be related to the characteristics of the technology, and in particular to the fixed costs of R\&D. This exercise shows that it is the relative and not absolute strength of technology that matters. Profit is a reward for relative superiority when compared to the set of all other (actual and potential) technologies in the industry, and in particular to the strongest competing technology.

An important feature of the industry model is that the location of both $R \& D$ and headquarters are endogenous: technology-owners can choose where to locate headquarters and R\&D. It used to be assumed that firms were locked in to their R\&D locations, e.g. because research was embedded in a local community of practice and could not be relocated. Another argument was that R\&D needed to be near headquarters so that it could be kept under close surveillance, which implicitly assumed that the firm was locked into its headquarters location. Recently this view has been challenged. R\&D may 
benefit from being located close to the principal customer, or close to the principal production plant, while headquarters may benefit from being close to the geographical hub of the firms operations, or to a financial centre or tax haven. The industry model analyses all of these options.

\section{SUMMARY OF THE MODEL}

The structure of the model is illustrated schematically in Figures 1 and 2. Figure 1 highlights top-level rivalry between technologies serving individual country markets within the global economy. The figure shows just two markets, but any number is possible. Three technologies are shown in the figure, but again any number is possible. They may be existing technologies already in operation, or new technologies awaiting innovation.

Figure 1: Relation of technologies to markets

$$
\begin{array}{lll}
\text { Technology } 1 & \text { Technology } 2 & \text { Technology } 3
\end{array}
$$

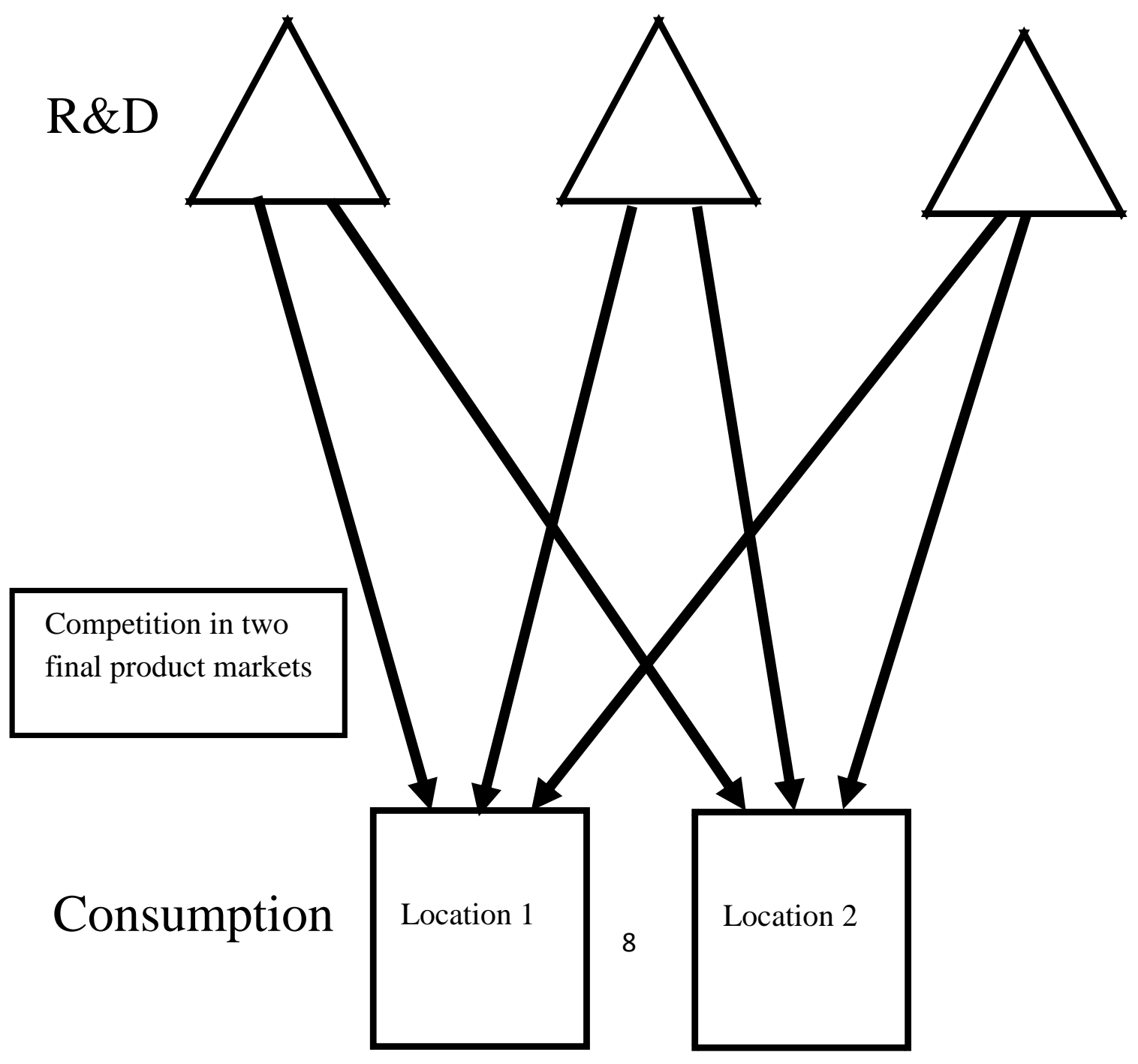


The way in which a given technology serves a given market is illustrated in Figure 2. For simplicity the two-country case is retained. The technology-owner may headquarter their operations in either country. If the owner is a private inventor they are free to choose where to establish their headquarters, i.e. they can migrate to wherever they like. The headquarters of an established firm, on the other hand, may be relocated through takeover or merger (either friendly or hostile), or simply by re-registration.

The owner of a technology does not have to own production too. They can license their technology to an independent producer who supplies the market themselves. Alternatively they can retain the ownership of the product but subcontract its production; in this case the subcontractor owns the production plant but the technology-owner retains the right to sell the product. The subcontractor is paid for simply for the labour and capital services they supply. For both production and R\&D, the question of who owns the activity is separate from the question of where the activity is located.

A technology-owner's headquarters coordinates the flow of knowledge from $R \& D$ to production and the flow of product from production to customer. When technology is licensed the licensee's headquarters takes over responsibility for the second step. Where subcontracting is concerned the technology-owner's headquarters continues to coordinate the flow of product through to the customer whilst the subcontractor's headquarters controls the internal operations of the plant.

When production takes place under constant returns to scale the ownership and location of production are determined independently for each market. As usual, location is influenced by factors such as international production costs differentials, transport costs and tariffs, whilst ownership is influenced by the costs of licensing. Ownership and location are linked by the 'liability of foreignness' (Zaheer, 1995) or the 'cost of doing business abroad' (Hymer, 1976) e.g. some low-cost production locations may incur additional political risks. 
Figure 2: A supply chain in the two-location case

\section{Location 1}

Technology-owner's decisions on:

Location of headquarters

Location of R\&D

Intermediate product market coordinating flow of knowledge from R\&D to production

Location of production decision

Choice of contractual arrangements:

Ownership of product

Ownership of plant

\section{Location 2}

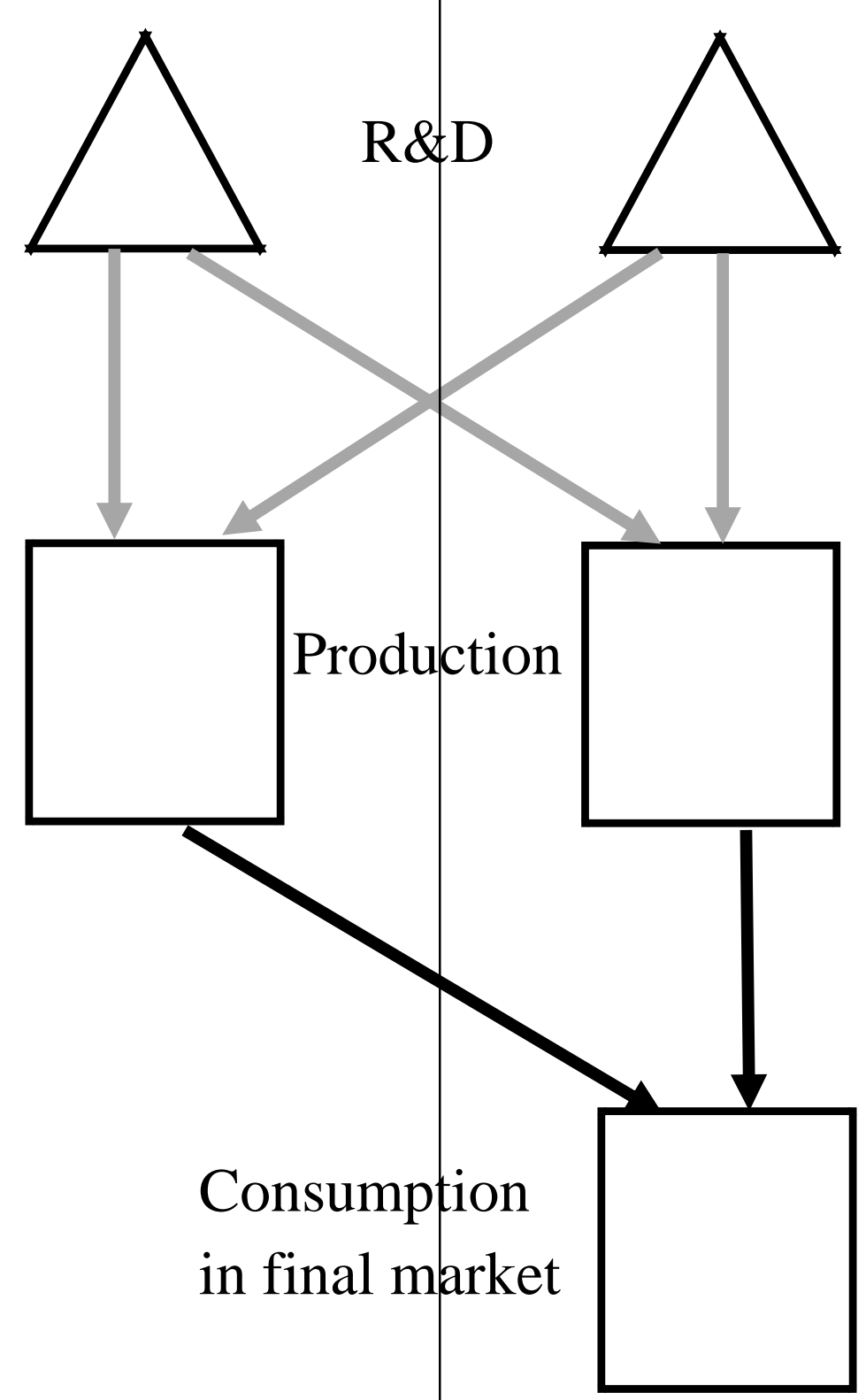

Key:

Knowledge

flow:

Final product

flow 
The ownership and location of R\&D are determined differently. While production decisions are tailored to the needs of individual markets, $R \& D$ decisions relate to the global economy. Decisions regarding $R \& D$ influence the costs of serving every market, and so to weigh up alternative $R \& D$ strategies it is necessary to know market sizes and to assess which markets will be served. By optimising their market entry into each potential market, and comparing their unit costs with the prevailing price, each technology-owner can assess whether they can afford to serve the market. In this way they can determine the profit that they can make from each market and, by aggregation, their overall profit. Subtracting the fixed cost of R\&D from gross profit gives the net profit they will earn. This net profit will vary according to which other technologies are innovated, and where the innovators locate their own headquarters and R\&D.

For each possible innovation scenario each technology-owner decides, by rational calculation, whether they will innovate. Some sets of innovation decisions made by different technology-owners will be mutually compatible, in the sense that each individual decision is rational given the decisions that the others have made. Such sets of rational decisions constitute equilibria for the game in which the technology-owners are engaged. When all the technology-owners move simultaneously there may be more than one equilibrium to the game, but if they move sequentially then a unique equilibrium is virtually guaranteed; the exception is where alternative strategies yield the same technology-owner equal profits. It is possible that there may be no equilibrium in the simultaneous game, but this is most unlikely in practice; provided that the parameter values are realistic, at least one equilibrium will normally exist.

\section{SOLUTION OF THE MODEL}

\section{Economic Logic: Three Levels of Analysis}

The model presented here is a special case of a general type of model that is well-known in the economics literature, namely the multi-player non-cooperative game. Considered as a game, the model has three distinctive features. The first is that the pay-offs are generated entirely by IB theory, and in 
particular by internalization and location decisions. The second is that the game is not a standard oligopoly game, with a pre-determined number of firms, but an innovation game in which the number of firms is endogenous. Thirdly, the innovators do not simply decide whether to innovate or not; they also make strategic choices about where to innovate, and in particular where to locate their R\&D and their headquarters.

The solution of the model determines the number of technologies that are innovated, the profit accruing to each technology-owner, the markets served using each technology, the prices prevailing in each market, and the supply chain strategies used to serve each market, including the location of production, the ownership of product, and the use of subcontractors. The ownership of the product is governed by whether licensing takes place. The location of headquarters and the location of $R \& D$ for each technology in use are also determined.

The solution of the model relates these outcomes to a set of key parameters. Together these parameters determine all aspects of an industry and its structure. They comprise the structure of demand in each market, i.e. the size of the market and the maximum price that customers will pay, and the cost parameters associated with each technology. All parameters are location-specific, reflecting the importance of geography in IB.

The relevant cost parameters are listed in Table 1. They are classified into resource costs and coordination costs. Institutional factors are a major influence on coordination costs. Costs may be incurred both within facilities (e.g. production plants, R\&D laboratories) and also in linkages between facilities. Variable costs are itemised in the left-hand column and fixed costs in the right hand column. Variable costs are directly proportional to the quantity of product, and the relevant parameters are expressed as unit costs. Variable costs are incurred only when production commences, while fixed costs are incurred beforehand, and are therefore regarded as sunk. Fixed costs are independent of the amount produced and the number of markets served. 
Table 1: Classification of costs for a given technology

\begin{tabular}{|l|l|l|}
\hline \multicolumn{2}{|l|}{$\begin{array}{l}\text { Nature of cost } \\
\text { Unit costs) }\end{array}$} & Fixed costs (sunk) \\
\hline Resource costs & $c(1)$ Production cost (location) & $\begin{array}{l}f(1) \text { R\&D establishment costs } \\
\text { (location) }\end{array}$ \\
\hline Facilities & $\begin{array}{l}c(2) \text { Trade costs (production } \\
\text { location, local market) } \\
c(3) \text { Technology transfer cost } \\
\text { (R\&D location, production } \\
\text { location) }\end{array}$ & \\
\hline Coordination costs & $\begin{array}{l}c(4) \text { Costs of licensing } \\
\text { (ownership of R\&D, ownership } \\
\text { of production) } \\
c(5) \text { Marketing cost (ownership } \\
\text { of production, local market) }\end{array}$ & $\begin{array}{l}f(2) \text { Coordination of R\&D } \\
\text { (R\&D location, headquarters } \\
\text { location) }\end{array}$ \\
\hline Facilities & $\begin{array}{l}c(6) \text { Costs of quality control } \\
\text { (product ownership, production } \\
\text { location, subcontracting } \\
\text { decision) } \\
c(7) \text { Costs of managing } \\
\text { political risk in production } \\
\text { (product ownership, production } \\
\text { location, subcontracting } \\
\text { decision) }\end{array}$ & $\begin{array}{l}f(3) \text { Technology-owner's } \\
\text { headquarters establishment } \\
\text { costs (location) } \\
f(4) \text { Cost of maintaining secrecy } \\
\text { in research (R\&D location) } \\
f(5) \text { Costs of upholding } \\
\text { intellectual property rights in } \\
\text { product (headquarters location) }\end{array}$ \\
\hline
\end{tabular}

Notes: Terms in brackets indicate the dimensions along which a parameter value varies.

Consider variable costs first. According to Figure 2 the two main linkages are the flow of technology from R\&D to production, where technology transfer costs are incurred, and the flow of product to market, where trade costs are incurred (these comprise transport costs, tariffs and non-tariff barriers). The coordination of technology incurs licensing costs (the gains from internalization foregone), while the coordination of distribution incurs marketing costs. The ownership of production facilities incurs political risks, and also costs of quality control; these two costs are traded off against each other in the subcontracting decision.

Fixed costs relate to the location of $R \& D$, the location of headquarters, and the proximity of the two.

Establishment costs are incurred by both R\&D and the headquarters of the technology owner.

Coordination costs may increase when $\mathrm{R} \& \mathrm{D}$ and headquarters are at different locations (a linkage effect). An inappropriate choice of R\&D location may lead to loss of secrecy and consequent imitation 
of the product, whilst an inappropriate choice of headquarters may make intellectual property rights such as patents difficult to enforce.

The model involves three main levels of analysis.

The top level determines:

- Which technologies are innovated;

- The location of the R\&D for each innovation; and

- The location of the headquarters.

Top-level decisions are modelled as a non-co-operative game played out between technology-owners, as explained above.

The middle level determines:

- Which technologies serve which markets;

- The price in each market;

- The profits generated in each market

These outcomes are all determined by competition between innovators. Unlike top-level technological rivalry, which takes place at the global level, middle-level competition takes place in individual markets at the country level. There are no sunk costs of market entry, and so, once innovation has been made, entry is free into each market. Customers drive a competitive price adjustment process. In each market firms bid down supply price until only the least-cost supplier can break even. The profit accruing to the successful supplier reflects the cost advantage of the least-cost supplier relative to other suppliers, and the size of the market.

The bottom level of the model determines the classic outcomes discussed in IB theory, namely the location and ownership of production. The model makes a three-way distinction between;

- The location of production;

- The ownership of the product; and 
- The ownership of the plant.

Outcomes emerge from negotiations between each technology-owner and their potential licensees and subcontractors; by playing them off against each other the technology-owner appropriates all the rents. For each technology the production location for each market is optimised independently, conditional on the locations of $R \& D$ and headquarters. As a result, the same technology-owner may serve different markets using different arrangements.

The solution of the model involves first carrying out the bottom level of analysis, where the lowest cost supply strategy for each individual market is found for each technology. This then allows the middle level of analysis to be performed where the outcome of competition between the technologies determines which serves each market, at what price, and with what level of profit. This analysis is performed across multiple scenarios, where each scenario involves a possible set of outcomes from the top level of analysis for each technology. Having completed the middle level, it is then possible to carry out the top level of analysis which finds a competitive equilibrium which determines which technologies are innovated, where each firm's headquarters are located, and each firm's R\&D location.

The solution determines not only how individual firms behave, but which types of firms exist, and the numbers of each type. Some technologies may not be viable, in the sense that they cannot make a profit in the face of competition from others, and so the firms that would have exploited them do not exist because innovation never occurs. Licensees exist only when the owner of a viable technology decides to license it, e.g. because the market they plan to serve is remote from their headquarters. Subcontractors exist only if the owner of a viable technology decides to out-source production, e.g. because they are unfamiliar with local conditions. The existence of any one firm depends on the coexistence of partner firms (i.e. licensees and subcontractors), and the absence of others (i.e. rival technology-owners). The set of firms that operate in the industry is therefore endogenous, as emphasised above.

In terms of internalization theory, the model determines all the boundaries between firms in the global industry. Unlike simple expositions of internalization theory, it does not focus on just a single linkage 
or a single firm. The model ensures that in equilibrium all the boundaries are consistent with each other.

The results contain within them all the standard results on choice of market entry mode. These are augmented by new results relating to additional entry modes that have not previously been analysed. In the special case of two countries, for example, there are 16 entry modes to a foreign market, whereas conventional theory normally distinguished only three: exporting, licensing and FDI. Casson and Wadeson (2012) have identified a fourth entry mode, in which a licensee exports to the foreign market. The additional modes arise because the model conditions market entry on the ownership and location of $R \& D$; with four $R \& D$ strategies and four entry modes associated with each there are 16 entry modes altogether (see Table 2). In the many-country case there are additional options based on off-shore production, which are in turn conditioned on a wider range for options involving off-shore R\&D.

Because of the large number of options, the marginal conditions governing the choice of entry mode are quite complicated, although perfectly well-defined. There is insufficient space to enumerate them here, but their application is illustrated through practical examples in section 6. No single parameter dominates the choice of entry mode; it is the interactions between them, based on their relative values, that are crucial.

The analysis of entry modes is embedded within the wider issue of whether certain markets should be served at all, and even whether certain technologies are worth innovating. Furthermore the analysis is applied simultaneously to every firm within the industry and not to just a single firm selected for special study.

The overall solution is governed by the entire set of parameter values introduced above. This set reflects the physical, technological and institutional environment of the global industry. Industry parameters are different from the parameters that appear in the analysis of a single firm, e.g. in a competitive local market price is exogenous to a single firm but endogenous for the industry as a whole. The solution of the model depends on both absolute and relative parameter values. For 
example, if all unit costs are scaled by the same proportion then the least cost supply strategy for each market remains the same; supply strategy changes only when relative values change. Given the importance of relative parameter values, it is crucial to identify underlying causes of their variation. By appealing to conventional IB theory it can be seen that characteristics such as the tacitness of technology are reflected in the resource costs of technology transfer, attitudes to property rights are reflected in the costs of licensing; and product characteristics, such as size and perishability, are reflected in transport costs. Location-specific variation is related to notions of distance, which include institutional distance (political, cultural) as well was geographical distance. The wide range of parameters deployed in the model ensures that it is consistent with the institution-based view of IB (Hoskisson, Wright, Filatotchev and Peng, 2013).

Table 2: Alternative strategies for serving a given market using a given technology in the twocountry case

\begin{tabular}{|c|c|c|c|c|}
\hline \multicolumn{4}{|c|}{ Location } & \multirow[b]{2}{*}{ Description of market-entry strategy } \\
\hline $\begin{array}{l}\text { R\&D } \\
\text { HQ }\end{array}$ & R\&D & Prod'n & $\begin{array}{l}\text { Prod'n } \\
\text { HQ }\end{array}$ & \\
\hline \multicolumn{5}{|c|}{ Technology-owner headquartered in country $1, R \& D$ co-located } \\
\hline 1 & 1 & 1 & 1 & Export \\
\hline 1 & 1 & 1 & 2 & Licensing to an off-shore producer from host market \\
\hline 1 & 1 & 2 & 1 & Import-substituting FDI \\
\hline 1 & 1 & 2 & 2 & Licensing \\
\hline \multicolumn{5}{|c|}{ Technology-owner headquartered in country $1, R \& D$ off-shored } \\
\hline 1 & 2 & 1 & 1 & Exporting with FDI in $R \& D$ \\
\hline 1 & 2 & 1 & 2 & Licensing to off-shore producer with FDI in $R \& D$ \\
\hline 1 & 2 & 2 & 1 & FDI in production and $R \& D$ \\
\hline 1 & 2 & 2 & 2 & Licensing with FDI in $R \& D$ \\
\hline \multicolumn{5}{|c|}{ Technology-owner headquartered in country $2, R \& D$ off-shored } \\
\hline 2 & 1 & 1 & 1 & Host-market FDI in R\&D with licensing to exporter \\
\hline 2 & 1 & 1 & 2 & Host-market FDI in R\&D and off-shore production \\
\hline 2 & 1 & 2 & 1 & $\begin{array}{l}\text { Host-market FDI in } R \& D \text { with licensing to foreign-owned } \\
\text { domestic producer [Normally dominated by the strategy } \\
\text { below] }\end{array}$ \\
\hline 2 & 1 & 2 & 2 & Host-market FDI in R\&D with domestic production \\
\hline \multicolumn{5}{|c|}{ Technology-owner headquartered in country $2, R \& D$ co-located } \\
\hline 2 & 2 & 1 & 1 & Host-market licensing to exporter \\
\hline 2 & 2 & 1 & 2 & Host-market off-shore production \\
\hline 2 & 2 & 2 & 1 & $\begin{array}{l}\text { Host-market licensing to foreign-owned domestic producer } \\
\text { [Normally dominated by the strategy below] }\end{array}$ \\
\hline 2 & 2 & 2 & 2 & Domestic production in host market \\
\hline
\end{tabular}

Note: The market to be served is in location 2. A similar analysis applies for location 1. 
At a more intuitive level, the analysis suggests that each industry may be regarded as an eco-system populated by a diverse collection of firms. These firms interact through both competition and cooperation. Environments vary across industry eco-systems and these variations will be reflected in different patterns of IB, e.g. between manufacturing and service industries, high-technology industries and low-technology industries, industries with customised products and those with standardised products, and so on. Following Spender (1989), the model can generate industry-level predictions without recourse to a stereotypical firm.

A global industry may encompass different industrial districts in different parts of the world. Each of these districts can be regarded as a local eco-system, and each local system may have a distinctive role. The model can be used to compare and contrast these local systems.

Parameter values may change over time, and as they do so the ecology will change as well. Industry structure will adapt to the new conditions. Existing firms may exit the industry, or redraw their boundaries, or enter or exit new markets, and new firms may appear.

Change over time can be analysed by the method of comparative statics, which compares the initial state of the system with the final one. The model is solved under the initial parameter values, and again under the new ones, and the differences are noted. The model can identify the 'tipping points' at which radical changes occur. This is illustrated by the examples below.

\section{PRACTICAL APPLICATIONS}

\subsection{Industry evolution and the interplay between industry-specific and firm-specific effects}

By situating an MNE within the context of an industry it is possible to distinguish between industryspecific effects and firm-specific impacts on firm strategy. Furthermore, by viewing industry evolution in historical perspective it is possible to identify key industry-specific drivers of change. For example, one can interpret the evolution of the automobile industry (Foreman-Peck, 1986; Sturgeon, van Biesebroeck and Gereffi, 2008) as being driven mainly by industry-specific effects, with firm-specific effects governing the speed with which different firms responded to industry-wide change. Indeed, in this industry, failure to speedily adapt firm-specific business models to a changing business 
environment has been the main determinant of who 'wins' and who 'loses'. Key industry parameters changed significantly over the post-war period 1945-2015. Tariff protection was reduced, first on automotive components and then on fully assembled vehicles. Precision engineering based on interchangeable parts was refined into modular design, whereby a small set of key components (engines, transmissions, chassis, etc.) could be packaged in different ways to produce vehicles aimed at different market niches. Programmable robots replaced customised machinery, making factory equipment more versatile and footloose. Containerization reduced the cost of shipping components, and ro-ro vessels the costs of shipping completed vehicles, whilst computerised logistics reduced the time-related inventory costs of goods in transit (Iammarino and McCann, 2013). In terms of the model, trade costs were reduced, first for intermediate products and later for final products. The resource costs of technology transfer were also reduced. In the early post-war period effective protection of assembly was high, because tariffs were higher on vehicles than on components, and this encouraged importsubstituting FDI in assembly. Subsequently, modularization facilitated the international rationalization of component production. Production of high-technology components such as engines and transmission systems was concentrated in mature industrialised economies, with low-technology components being produced in newly industrialising countries, but gradually reductions in the costs of technology transfer shifted production of high-technology components to low-wage economies too. An increasing range of components, including bulky low-value items such as tyres, became widely traded. When tariffs on assembled vehicles were reduced, production was rationalised so that certain models were produced only in certain countries - the industry also became regionalised which resulted in overcapacity in the more industrialised countries (Holweg, 2008). As a result, in stark contrast to the declining markets in North America, Europe and Japan, manufacturing in the Republic of Korea has been growing steadily from 1985, whereas South America and India gave experienced substantial growth since the 1990s, with China growing steadily from around 2000 (Oliver et al, 2009). R\&D was rationalised as well as production, with a few key cities and regions emerging as global innovation hubs. These changes affected all firms in the industry. But some firms were quicker than others to embrace new technologies. These included not only 'hard' technologies such as modularization and robotics, but also 'soft technologies' such as 'just-in-time' production, zero-tolerance quality control, 
and cellular teamwork. New entrants from South-east Asia were more innovative than established producers in the US and Europe. They recognised that environmental change was altering the economic logic of the global auto industry and that traditional industry recipes needed to be replaced. Whereas Western manufacturers responded by striving to increase volumes and market coverage (alliances between Daimler-Benz, BMW and Rover, General Motors and Fiat, all failed), South-east Asia firms responded by being first to adopt these superior manufacturing methods.

To analyse the evolution of the post-war auto industry, therefore, it is necessary to examine the interactions between a heterogeneous groups of firms that reacted to common shocks in individualspecific ways. The complexity of this situation can overwhelm the analyst unless a suitable model is employed. Conventional economic models are too general for this purpose because their assumption of firm homogeneity is too far-reaching. Existing IB models, on the other hand, play down industry effects and tend to focus on the strategies of individual firms without investigating how these strategies interact. The model presented above, however, is well suited for this purpose.

\subsection{Analysing prices trends in global industries}

Prices play a central role in international trade and yet they are rarely discussed explicitly in the IB literature. Prices have a prominent role in an industry model because they communicate to each firm the strength of the competition they face in serving each local market. By comparing prices with unit costs mangers can avoid making losses in individual markets, thereby ensuring efficient market sourcing throughout the global industry. Prices also influence innovation decisions through their impact on profitability.

Many changes in the post-war economy have been associated with dramatic changes in prices. The model shows how price data can inform the analysis of industry evolution. Whilst general changes in the price level are often caused by monetary factors, changes in relative prices are generally associated with structural change. To analyse structural change over time it is useful to adjust price data for the cost of living and product quality. Over time the real prices of non-renewable resources have tended 
to increase, while the real price of manufactured goods has tended to fall. This tendency is most apparent in highly innovative industries such as laptop computers and mobile phones (Grimm, 1998).

IB theorists tend to assume that innovators earn monopoly profits, but in a highly innovative industry monopoly profit may be only temporary. Rapid innovation implies rapid obsolescence. Sustained innovation drives down industry price, and over time this may transform an industry from nicheproduction of luxury products into the mass-production of popular brands and finally, perhaps, into commodity production of a standardised good (Vernon, 1971). As an innovative industry follows through the product life cycle, it tends to move from quality-based competition to cost-based competition. Radical innovation devoted to quality improvement in the early phase is superseded by incremental innovation devoted to cost-reduction. The cumulative knowledge embodied in the product increases throughout the cycle, but the proportion of new knowledge decreases, making the protection of intellectual property less important. As a result, licensing and subcontracting become less costly later on. The model provides a rigorous account of this complex chain of causation in a highly innovative industry.

The model also demonstrates an interesting connection between globalization, innovation, prices, profits and the distribution of income. In this context, globalization may be identified with a significant reduction in trade costs, knowledge transfer costs and the costs of foreignness. Globalization stimulates innovation because it makes it easier for an innovator to serve a global market, and so increases prospective profits. A one-off radical innovation will yield a large profit but it may not be sustained once it has been imitated or becomes obsolete. An incremental innovation will make a smaller profit, which is also likely to be transitory, but serial innovation effected by the same entrepreneur can earn a sequence of transitory profits and so make the entrepreneur extremely wealthy (see Table 3). In a competitive environment serial innovation will drive down prices quickly and thereby benefit consumers, whilst at the same time making one person very rich. In this case, globalization stimulates innovation, which stimulates price reductions whilst generating a steady stream of profits, which leads to the accumulation of wealth by a single serial entrepreneur. If this process is replicated across sufficient industries then it is sufficient to generate a class of super-rich 
serial innovators, who confer consumer benefits through price reductions whilst stimulating envy and admiration for the wealth they accumulate for themselves.

Table 3 Impact of innovation on prices and profits

\begin{tabular}{|c|c|c|c|}
\hline & \multirow{2}{*}{$\begin{array}{l}\text { Occasional } \\
\text { Solitary } \\
\end{array}$} & \multicolumn{2}{|l|}{ Frequent } \\
\hline & & Solitary & Serial \\
\hline Incremental & $\begin{array}{l}\text { Modest persistent profits } \\
\text { for a few technology- } \\
\text { owners } \\
\text { Slow price reductions: } \\
\text { limited and intermittent }\end{array}$ & $\begin{array}{l}\text { Modest transitory profits } \\
\text { for many technology- } \\
\text { owners. } \\
\text { Moderate-speed price } \\
\text { reductions: limited but } \\
\text { frequent }\end{array}$ & $\begin{array}{l}\text { Large persistent } \\
\text { profits for a few } \\
\text { technology-owners. } \\
\text { Fast price reductions: } \\
\text { large and frequent } \\
\text { reductions }\end{array}$ \\
\hline Radical & $\begin{array}{l}\text { Large persistent profits } \\
\text { for a few technology- } \\
\text { owners } \\
\text { Moderate-speed price } \\
\text { reductions: large but } \\
\text { intermittent }\end{array}$ & $\begin{array}{l}\text { Large transitory profits } \\
\text { for many technology } \\
\text { owners. Fast price } \\
\text { reductions: large and } \\
\text { frequent }\end{array}$ & \\
\hline
\end{tabular}

\subsection{Headquarters Location, Regional MNEs and Technology-seeking Investments}

When analysing an individual firm it seems perfectly reasonable to take as given the existence of the firm, the location of its headquarters and the location of its R\&D. If the same approach is extended to the industry level, however, it implies that an industry consists of a fixed number of firms, each locked in to a particular headquarters and a particular location for R\&D. Whilst this might be acceptable for short-run analysis, it is unsatisfactory for a long-run analysis of industry evolution.

Headquarters location determines the 'nationality' of the firm, and as such determines the 'foreignness' or otherwise of all locations in the global economy. Given the fundamental role of costs of foreignness in IB theory, a firm exploiting a given technology may wish to locate its headquarters close to the 'centre of gravity' of its operations (Bei and Fageda, 2008). This centre of gravity is determined by the national markets that it serves, which in turn influence the locations at which it produces.

IB theory tends to assume that cost of foreignness is very high in respect of $R \& D$; hence the view that headquarters and R\&D will be co-located. Costs of foreignness are most frequently invoked with 
respect to production, because international technology transfer is assumed to carry a substantial cost premium relative to domestic transfer. The costs of selling in a foreign market have received less attention, however. Yet these costs are crucial to two major issues in IB theory, namely regional MNEs and technology-seeking investments.

The regionality of MNEs can be measured either in terms of sales or production (Rugman, 2005). Much of the emphasis has been on sales, partly because of data availability. But emphasising sales suggests that costs of foreign marketing are a major cause of regionality. These costs could be avoided by licensing, but advocates of regionalism often assume (possibly correctly) that licensing is inferior to exports or FDI. If costs of foreignness in marketing are inter-regional rather than international, then costs of foreign marketing are an obvious explanation of regional MNEs.

Costs of foreign marketing are also a simple explanation of technology-seeking investment. If the owner of a technology desires to internalise its exploitation but cannot easily sell the product in some major foreign market then it may be efficient for a firm headquartered in that foreign market to take over the technology itself. Technology seeking investment includes four of the 16 modes of entry listed in Table 2. In terms of the model the technology seeker simply becomes the owner of the R\&D. The barrier to serving the market is overcome by changing the headquarters location; instead of colocating headquarters and R\&D, headquarters and market are co-located instead. In terms of the industry model, if the pull of the market in the industry is greater than the pull of R\&D then firms' headquarters will gravitate to their markets instead.

Consider for example recent Chinese acquisitions of R\&D-intensive European firms. Many of these acquisitions appear to be alternatives to licensing European technology. The costs of licensing are likely to be high because European firms would not trust their Chinese partner to respect the restrictive conditions under which a license would be given. It also seems that a major reason for acquiring the technology is to serve the large domestic market in China (Niosi and Tschang, 2009). European firms, however, find it difficult to market in China because for cultural reasons they do not understand the customers well. 
Regionalism and technology-seeking both have wider implications which are made explicit by the industry model. With low costs of foreign marketing, a solitary global firm headquartered in a hightechnology country can serve the entire market. There could be multiple firms, however, provided that the fixed costs of R\&D are low. But a regional firm cannot, by definition, supply the entire global market. Either some markets are not supplied, or there are multiple firms. If there are multiple firms then economic logic suggests they will each focus on a particular region rather than share the same one. With each market a regional monopoly, prices will be higher than under global competition, but profits may be lower because of greater replication of R\&D. The industry model therefore shows a link between the nature of firms (regional or global), the number of firms, the level of prices and the profitability of firms. Overall, regionalism performs poorly in terms of efficiency because of the constraint imposed by foreign marketing costs.

When regionalism prevails, technology-seeking firms and market-seeking firms may co-exist. Suppose that there is only one location in the world where industry $R \& D$ can be carried out. Because of foreign marketing costs, each regional market will be served by a locally headquartered firm. In the region where the R\&D is based, the regional MNE resembles a conventional market-seeking firm since it is free to locate adjacent to its $R \& D$. However, in the absence of licensing, the other regions will be served by technology-seeking firms who have to off-shored their R\&D. Only an industry model can make explicit this connection between technology-seeking and regional MNEs.

\subsection{Sunk Costs and Competition in a Global Industry}

It is well known that high sunk costs increase the credibility of entry-deterrence in oligopolistic industries (Petit and Sanna-Randaccio, 2000). The model confirms this result, and also shows that high fixed costs lead to fewer firms, and a switch from regional to global MNEs. A useful application is the global pharmaceutical industry. In the pharmaceutical industry the most profitable opportunities afforded by post-war scientific advances have now been exploited, and the costs of gaining approval for new products have risen significantly. As a result, the shake-out predicted by the model has occurred. Transnational mergers have merged regional MNEs into global MNEs (e.g. Glaxo Smith Kline). The model also predicts the relocation of $R \& D$ to lower-cost locations which has occurred in 
certain areas of research. The model also helps to explain growing political controversy over pharmaceutical pricing. With less innovation, price decline may slow because obsolescence decreases, and the associated reduction in the number of firms may make collusion easier, and strengthen market power. In terms of public policy, this scenario would reinforce the case for stronger international regulation of industry pricing. In this connection, the link between price regulation and competition is documented in Danzon \& Chao (2000) while numerous studies have identified the potential threat of price controls for R\&D investment (Giaccotto et al., 2005; Vernon et al., 2006). This illustrates the fact that industry models, when empirically calibrated, have public policy implications that individual case studies cannot normally provide.

\section{CONCLUSIONS}

This paper has responded to Rugman's call for a re-focusing of IB studies around the continued development of core theories. Internalization theory was first developed to explain inter-industry patterns in FDI. The logical way to do this was through an analysis of an industry rather than a firm. But game theory was not fully developed at the time. For the past twenty years research on internalization has followed a different trajectory to research on international oligopoly. There is now an opportunity to integrate these two strands of theory within a single model.

The model shows that many strategic decisions are inter-dependent - not only within the firm but between firms. This is particularly true of innovation and the location of headquarters and R\&D. In line with the principles of internalization theory, the model explains the nature of the firms that exist and the scope of each firm's operations. Different types of firm co-operate (technology-owners, licensees and subcontractors) and similar types of firm compete. The model distinguishes two levels of competition, namely local competition in individual markets, and global competition involving R\&D and headquarters locations. Local competition is mediated by prices, whereas global competition involves strategic commitments to innovation. 
Global competition selects superior technologies. It selects them, however, not on the basis of technological excellence, but on profitability. Profitability depends, in turn, on a range of geographical and institutional factors. The advantage enjoyed by a global technology is not therefore an intrinsic absolute advantage but a contingent relative advantage that is affected by a range of geographical and institutional factors. Given that advantages are not intrinsic, it may be appropriate to reconsider the use of the concept of 'ownership advantage' in explaining IB behaviour (Dunning and Lundan, 2008).

The model explains heterogeneity and diversity both within industries and between industries. It addresses directly the question of why different industries exhibit different patterns of FDI, and also explains why different types of firm are found in the same industry. It also explains diversity within the firm, whereby different supply chains strategies are used to supply different markets.

The solution of the model highlights the fact that within the IB system, outcomes are not normally determined by the managerial decisions of any single firm, but rather by the interplay of decisions made by different firms. The closest approximation to managerial autonomy involves a global system completely dominated by a single firm that owns a low-cost technology that allows it to serve every market by exports or FDI. But as soon as other low-cost technologies enter the industry, a dominant firm must face up to competition in local markets, and competitive pressures then begin to influence market outcomes.

Competition means that some firms are viable and others are not. IB models that simply assume the existence of a given type of firm, and relate performance directly to management actions, therefore violate the principles of this model by ignoring 'system' effects. Firms only exist if they can survive competitive pressures, and the survivors are those that respond efficiently to the constraints imposed by the industry environment. In IB these constraints operate at the global as well as the local level. In other words, the performance of a successful firm must be understood in terms of the weaknesses of its competitors as well as its own innate strengths.

As the global environment changes, so the IB system changes as a result of both adaptation and survival. Old technologies may be re-introduced as well as new ones developed. Changes in transport 
costs and trade policies may stimulate innovation even though no advance in scientific knowledge has occurred. When demand parameters change as the result of new or emerging markets, some technology-owners may change their strategies (e.g. relocate their R\&D or headquarters), whilst others may become unprofitable, and their technologies go out of use. According to the model, it is not only technological progress, but also emerging profit opportunities, that govern the dynamics of the IB system.

The framework presented in this paper is very general, and can encompass a wide range of countries and technologies. It generates many marginal conditions for the optimization of firm performance, but there are too many to describe in a single paper. Elaboration of the model therefore provides a very useful agenda. In the long-run the model can be developed further in various ways. A three-country variant of the model would make it possible to analyse Triad competition, and also to analyse thirdcountry location in global supply chains. Additional insights from innovation theory could be introduced, such as technological complementarity and recombination. Using repeated games would provide a deeper analysis of conflict and co-operation. Endogenising government behaviour is another possibility; this would allow the political economy of industry evolution to be analysed from an interdisciplinary perspective.

Indeed, a key feature of this model is that it follows the same principles as models in other branches of the social sciences, and thereby facilitates inter-disciplinary research. The model distinguishes a range of exogenous parameters and a set of endogenous variables whose values are simultaneously determined by the system. The causal links between the exogenous parameters and endogenous variables are governed by fundamental processes - in the present case by competition between profitmaximising game-playing rivals in a multi-country world. Innovation opportunities are the subject of a global game, and competition for market share is the subject of a local game. By adopting models of this type, IB theory can engage in productive dialogue with other social sciences, such as politics and economics, that use similar models. It may thereby overcome the growing isolation from these subjects that has characterised IB theory over recent years. 


\section{References}

Archibugi, D. \& Iammarino, S. 1999. The policy implications of the globalisation of innovation. Research Policy, 28: 317-336.

Barney, J., Wright, M. \& Ketchen, D. J. Jr. 2001. The resource-based view of the firm: Ten years after 1991. Journal of Management, 27: 625-641.

Bei, G. \& Fageda, X. 2008. Getting there fast: Globalisation, intercontinental flights and the location of headquarters. Journal of Economic Geography, 8(4): 471-495.

Beugelsdijk, S., \& Mudambi, R. 2013. MNEs as border-crossing and multi-location enterprises: The role of discontinuities in geographic space. Journal of International Business Studies, 44 (5): 413-426.

Beugelsdijk, S. B., van Ees, H., \& Garretson, H. (eds.) 2014. Firms in the International Economy: Firm Heterogeneity meets International Business, Munich: CESifo Seminar series.

Buckley, P. J. \& Casson, M. C. 1976. The Future of the Multinational Enterprise. London: Macmillan [25 $5^{\text {th }}$ Anniversary edition, 2001].

Buckley, P. J. \& Casson, M. C. 1985. Economic Theory of the Multinational Enterprise. London: Macmillan.

Buckley, P. J. \& Casson, M. C. 1998a. Model of the multinational enterprise. Journal of International Business Studies, 29 (1): 21-44.

Buckley, P. J. \& Casson, M. C. 1998b. Analysing foreign market entry strategies: Extending the internalization approach. Journal of International Business Studies, 29 (3): 539-561.

Buckley, P. J. \& Casson, M. C. 2009. The internalization theory of the multinational enterprise: A review of the progress of a research agenda after 30 years. Journal of International Business Studies, 40: $1563-1580$.

Buckley, P.J. and Casson, M. C. 2011. Marketing and the multinational, Journal of the Academy of Marketing Science, 39(2), pp.492-508. 
Buckley, P. J. \& Hashai, N. 2004. A global systems view of firm boundaries. Journal of International Business Studies, 35: 33-45.

Cantwell, J. A. 1989. Technological Innovation and Multinational Corporations. Oxford: Blackwell.

Cantwell, J. A. 2014. Revisiting international business theory: A capabilities-based theory of the MNE. Journal of International Business Studies, 45: 1-7.

Casson, M. C. 2013. Economic analysis of international supply chains: An internalization perspective. Journal of Supply Chain Management, 49 (2): 8-13.

Casson, M. C. \& Wadeson, N. S. 2012. The economic theory of international business: A supply chain perspective. Multinational Business Review, 20 (2): 114-134.

Casson, M. C. \& Wadeson, N. S. 2013. The economic theory of international supply chains: A systems view. International Journal of the Economics of Business, 20 (2): 163-186.

Coase, R. H. 1937. The nature of the firm. Economica (New Series), 4: 387-405.

Danzon, P. M. \& Chao L. 2000. Does regulation drive out competition in pharmaceutical markets? Journal of Law and Economics, 43 (2): 311-358.

DiMasi J. A. \& Grabowski H. G. 2012. R\&D Costs and returns to new drug development: a review of the evidence. In P. M. Danzon and S. Nicholson (Eds.), The Oxford Handbook of the Economics of the Biopharmaceutical Industry: 21-46. Oxford: Oxford University Press.

Dixon, H. 1990. Bertrand-Edgeworth equilibrium when firms avoid turning customers away. Journal of Industrial Economics, 39(2): 131-146.

Dunning, J. H. 1958. American Investment in British Manufacturing Industry. London: Allen \& Unwin.

Dunning, J. H. 1977. Trade, location of economic activity and multinational enterprise: A search for an eclectic approach. In B. Ohlin, P. O. Hesselborn and P. M. Wijkman (Eds.), The International Allocation of Economic Activity: 395-418. London: Macmillan. 
Dunning, J. H. 1993. Internationalising Porter's Diamond. Management International Review, 33 (2): $7-15$

Dunning, J. H. \& Lundan, S. M. 2008. Multinational Enterprises and the Global Economy. Second edition, Cheltenham: Edward Elgar.

Foreman-Peck, J. 1986. The motor industry, in Casson, M.C. (ed.) Multinationals and World Trade, pp.141-173, (London: Allen \& Unwin).

Fudenberg, D. \& Tirole, J. 1991. Game Theory. Cambridge, MA: MIT Press.

Giaccotto, C., Santerre, R. E., \& Vernon J. A. 2005. Drug prices and research and development investment behaviour in the pharmaceutical industry. Journal of Law \& Economics, 48(1): 195-214.

Graham, E. M. 1978. Transnational investment by multinational firms: A rivalistic phenomenon. Journal of Post-Keynesian Economics, 1: 82-99.

Grimm, B.T. 1998. Price indexes for selected semi-conductors, 1974-96, Survey of Current Business, February 1998: 8-24.

Hennart, J. F. 1982. A Theory of Multinational Enterprise. Ann Arbor: University of Michigan.

Hines, P., Holweg, M., \& Rich, N. 2004. Learning to evolve: A review of contemporary lean thinking. International Journal of Operations \& Production Management, 24(10): 994 - 1011.

Holweg M., 2008. The Evolution of Competition in the Automotive Industry. In G. C. Parry and A. P. Graves (Eds.), Build to Order: The Road to the 5-day car: 13-34, Springer.

Hoskisson, R. E., Wright, M., Filatotchev I., \& Peng, M. W. 2013. Emerging multinational from midrange economies: The influence of institutions and factor markets. Journal of Management Studies, 50 (7): 1295-1321.

Hymer, S.H. 1976. The National Operations of International Firms, Cambridge, MA: MIT Press. 
Iammarino, S. \& McCann, P. 2013. Multinationals and Economic Geography. Cheltenham: Edward Elgar.

Kirzner, I. M. 1973. Competition and Entrepreneurship. Chicago: University of Chicago Press.

Knickerbocker, F. T. (1973). Oligopolistic Reaction and Multinational Enterprise. Cambridge MA: Harvard University Press.

Krugman, P. R. 1991. Geography and Trade. Cambridge, MA: MIT Press.

Markusen, J. R. 2002. Multinational Firms and the Theory of International Trade. Cambridge, MA: MIT Press.

Milgrom, P. \& Roberts, J. 1982. Limit pricing and entry under incomplete information: An equilibrium analysis. Econometrica, 50 (2): 443-459.

Moon, H. C., Rugman, A. M., \& Verbeke, A. 1995. The generalised double-diamond approach to international competitiveness. Research in Global Strategic Management, 5: 97-114.

Mudambi, R. 2008. Location, control and innovation in knowledge-intensive industries. Journal of Economic Geography, 8 (5): 699-725.

Mudambi, R. and Venzin, M. 2010. The strategic nexus of offshoring and outsourcing decisions. Journal of Management Studies, 47(8): 1510-1533.

Niosi, J. \& Tschang, T. 2009. The strategies of Chinese and Indian software multinationals: Implications for Internationalisation Theory, Industrial and Corporate Change, 18(2): 269-24

Ohlin, B. 1933. Interregional and International Trade. Cambridge, MA: Harvard University Press.

Oliver, N., Holweg, M. \& Luo, J., 2009. The past, present and future of China's automotive industry: a value chain perspective. International Journal of Technological Learning, Innovation and Development, 2(1-2): 76-118. 
Petit, M. L. \& Sanna-Randaccio, F. 2000. Endogenous R\&D and foreign direct investment in international oligopolies. International Journal of Industrial Organization, 18: 339-367.

Petit, M. L., Sanna-Randaccio, F., \& Sestini, R. 2012. R\&D and foreign direct investment with asymmetric spill-overs. Economics of Innovation and New Technology, 21 (2): 125-150.

Ramamurti, R. \& Singh, J. (eds.) 2009. Emerging Multinationals in Emerging Markets. Cambridge: Cambridge University Press.

Rowthorn, R. \& Hymer, S. H. 1971. Internationa Big Business. Cambridge: Cambridge University Press.

Roy, A.S.A. 2012. Stifling new cures: the true cost of lengthy clinical drug trials. Project FDA Report, March (5). Manhattan Institute for Policy Research, New York.

Rugman, A. M. 1981. Inside the Multinationals: The Economics of Internal Markets. London: Croom Helm [25th Anniversary edition, 2007].

Rugman, A. M. (Editor) 1982. New theories of multinational enterprises. New York: St. Martin Press.

Rugman, A. M. 2005. The Regional Multinationals. Cambridge: Cambridge University Press.

Rugman, A. M. 2014. Letter from the editor. Multinational Business Review, 22 (3): 200-204.

Sanna-Randaccio, F. \& Veugelers R. 2007. Multinational knowledge spill-overs with decentralised R\&D: A game-theoretic approach. Journal of International Business Studies, 38: 47-63.

Schumpeter, J. A. 1934. Theory of Economic Development (trans R. Opie). Cambridge, MA: Harvard University Press.

Spender, J. C. 1989. Industry Recipes. Oxford: Blackwell.

Sturgeon, T., van Biesebroeck, J., \& Gereffi, G. 2008. Value chains, networks and clusters: Reframing the global automotive industry. Journal of Economic Geography, 8(3): 297-321. 
UNCTAD. 2011. World Investment Report 2011: Non-equity Modes of International Production and Development. Geneva: United Nations.

Vernon, J. A., Golec J. H., \& Hughen W.K. 2006. The economics of pharmaceutical price regulation and importation: refocusing the debate. American Journal of Law \& Medicine, 32: 175-192.

Vernon, R. 1971. Sovereignty at Bay. New York: Basic Books.

von Zedtwitz, M., \& Gassmann, O., 2002. Market versus technology drive in R\&D

internationalization: four different patterns of managing research and development. Research Policy, $31,569-588$.

Weber, A. 1929. Theory of the Location of Industries (ed. C.J. Friedrich). Chicago: University of Chicago Press.

Zaheer, S. 1995. Overcoming the liability of foreignness. Academy of Management Journal, 38(2): $341-363$. 


\section{Appendix}

This appendix presents the formal discrete-choice model of a global industry. Following Casson and Wadeson (2012), the model involves profit-maximising firms with well-informed managers. It is assumed that all variables except profits are non-negative, and the all maxima and minima are unique.

The model involves a technology set, a location set and a set of contractual arrangements. The technology set comprises a range of competing proprietary technologies. Each technology generates a different variety of product, but customers regard these variants as perfect substitutes for each other. Each technology therefore represents a different process for delivering the same bundle of services to the customer.

There is a set of locations; in general, each location can act as a site for production, $R \& D$ and headquarters, as well as a market. The 'law of one price' dictates that the same price prevails throughout each local market. A location may be interpreted as a country, city or a region sub-national or multi-country).

The set of possible contractual arrangements comprises outright ownership, licensing and subcontracting. The global industry is coordinated using the most profitable pattern of arrangements as determined within the model. The main components of cost incurred in serving foreign markets are summarised in Table 2.

Each technology is owned by a different firm, known as the technology-owner, which may license or subcontract to independent firms, but joint ventures are excluded. Each technology-owner is committed to a single technology, and there is no collusion or cartelization between them. Publicly available technologies are not discussed, but the model can be extended to include them.

Invention is an exogenous discovery process whilst innovation is an endogenous commercial process involving the commitment of resources to R\&D (Schumpeter, 1934); for simplicity, complementarities between innovations are ignored. Technology is a metaphor for any kind of knowledge embodied in a product, e.g. design or brand name, or indeed for any major profit-opportunity recognised by an entrepreneur (Kirzner, 1973). 


\section{Headquarters}

The exploitation of a technology is controlled from the technology-owner's headquarters. A headquarters is a unitary facility where legal title to ownership is asserted and from which production activities are coordinated. Headquarters monitors all production activities whose product is owned by the firm, and appropriates profit from them. No costs are sunk in a headquarters, but a technologyowner must commit to their headquarters location at the time that they innovate their technology.

\section{$R \& D$ Facilities}

$R \& D$ may be co-located with headquarters, or off-shored. $R \& D$ incurs a sunk fixed cost, which is expressed as a recurrent annual charge, comprising interest payments on the initial capital and recurrent expenses required to keep the technology up-to-date. For simplicity, it is assumed that R\&D is never subcontracted. Although small components of R\&D activity may, in practice, be subcontracted, the focus of the model is on strategic knowledge that the technology-owner must control.

\section{Markets and their Supply Chains}

The size of each market is determined by local demand. The simplest way of modelling demand is to assume that in each market each consumer demands one unit of product for which there is some maximum price (the 'reservation' price') that they are all willing to pay; this generates a rectangular demand curve associated with a fixed market size that is governed by the number of consumers. An alternative assumption is that demand in each market varies linearly with price; this generates a downward-sloping demand curve with a variable market size. Price-determination is straightforward in either case; the first approach simpler, though, and is the one used here.

Market size and reservation price vary across countries. Each market is served by a supply chain, comprising a single stage of production, which supplies product directly to customers. The production facility (or 'plant') may be owned by the technology-owner, or by an independent firm. Production costs depend on the technology and the location of production. The model can be generalised to a multi-stage supply chain, but becomes more complicated as a result. 


\section{Returns to Scale}

A crucial assumption is that production operates under constant returns to scale, and that factors of production, such as labour, are in infinitely elastic supply. This means that unit costs of production at each stage are constant, independently of the amount produced. Production for any given market is carried out in a single facility that is dedicated to it. Constant returns to scale implies that there is no advantage in combining co-located production activities into the same facility. This means that the locations of facilities that supply different markets are independent of each other.

\section{Coordinating Supply Chains: Subcontracting}

IB theory distinguishes carefully between the ownership of a technology and the ownership of a product produced using the technology. Following Casson (2013), the model further refines the concept of ownership by distinguishing between ownership of the product and ownership of the plant or facility in which it is produced. This makes it possible to analyse subcontracting arrangements in which product owned by one firm is processed by another. Subcontracting occurs when the owner of the product pays an independent owner of a plant to recruit and manage the labour force that generates the output. Subcontracting is an arm's length relationship between the owner of the product and the owner of the plant. The distinction is independent of whether the plant is owned or leased, and is also independent of the licensing decision (i.e. a licensee can also subcontract).

\section{Licensing Strategy}

It is often assumed that licensing is employed only when producing abroad (Dunning and Lundan, 2008). A formal analysis of the situation, however, shows that this is not necessarily correct (Casson and Wadeson, 2012). The option of domestic licensing is therefore included in the model.

\section{Economic Rents}

All rents from a proprietary technology accrue either to the technology-owner or their final customers. While there is only one owner of each proprietary technology, there are many potential licensees and subcontractors. They have similar abilities, and are unable to collude, and so compete against each 
other to participate in the supply chain. By playing them off against each other the technology-owner ensures that no rents are captured by other firms involved in the chain.

\section{Typology of Firms}

Within the global industry, the model identifies three types of firm:

- Technology-owners undertake $\mathrm{R} \& \mathrm{D}$ and appropriate rents from the proprietary knowledge that it generates. They can license their technology, own their product but subcontract production, or control production entirely themselves.

- Licensees acquire the right to a technology. They can produce in any country, but cannot undertake R\&D. They can subcontract. They appropriate no rents.

- Subcontractors do not own product but only production facilities. They can serve both technology-owners and licensees. They appropriate no rents and operate only in their headquarters country.

\section{Competition between Technologies to Serve a Given Market}

Rival technologies compete to supply each market. If no technology can serve a given market at a unit cost below the reservation price then that market is not served at all. If just one technology can serve a given market then it has a monopoly of that market, and the price is equal to the reservation price. If two or more technologies can serve the market then competition bids down price until the secondlowest cost technology just breaks even. The price is equal to the unit cost of the second lowest technology, and the lowest cost technology earns a competitive rent equal to the difference between the two unit costs. This process is consistent with both 'limit pricing' and Bertrand price competition (Dixon, 1990; Milgrom and Roberts, 1982).

\section{The Innovation Decision: Global Competition}

Each technology-owner decides whether to innovate and, if so, where to locate their headquarters and R\&D. When making decisions they take account of other technology-owners' decisions. Because 
innovation incurs fixed costs, competition is analysed in terms of game-playing rivalry. In equilibrium no innovator will make a loss, and no innovator who could make a profit will fail to do so.

Technology-owners may take their decisions either simultaneously or sequentially. In the case of simultaneous decisions, a Nash equilibrium exists when technology-owners' are mutually compatible. Each owner's strategy is an optimal response to all other owner's strategies. A Nash equilibrium may not exist, and if it does it may not be unique. Multiple Nash equilibria have some predictive value, because they identify, by exclusion, outcomes that will not prevail. The absence of any Nash equilibrium is more problematic, however. It can occur, for example, if one technology-owner prefers to locate R\&D at the same location as some other owner, whilst the other owner prefers to avoid such co-location.

When decision-making is sequential, the solution is derived using the principle of sub-game perfection, and can be calculated readily from a decision-tree. For any given sequence the solution is unique, but different sequences may lead to different outcomes (Fudenberg and Tirole, 1991). Given a unique equilibrium, detailed predications about the configuration of the industry may be derived, as indicated above. With sequential decisions a technology-owner may gain (and cannot lose) by committing to innovation early. If the most entrepreneurial technology-owner decides first they can appropriates any 'first mover' advantage.

Whether innovation decisions are sequential or simultaneous, the outcome may involve some, all or none of the technologies being innovated. The total profit made by each innovator depends on how many other innovators there are and where they locate their headquarters and R\&D.

\section{Notation}

Technologies are indexed $z=1, \ldots, Z$. There are $N$ locations (countries). Headquarters is located in country $q(z)$ and R\&D in country $r(z)$. If technology $z$ is innovated then $x(z)=1$ and otherwise $x(z)=$ 0 . The triple $(x(z), q(z), r(z))$ determines the innovation strategy for technology $z$.

Markets are indexed $l=1, \ldots, N$. There are $m(l)$ customers in country $l$, where the reservation price is $v(l)$. Production is associated with a location $i(z, l)$, a product-owner, $k(z, l)$, and a subcontracting 
indicator $s(z, l)$, which takes a value 0 if the facility is owned by the owner of the product, and 1 if there is subcontracting to a local firm. If market $l$ is served by technology $z$ then $x(z, l)=1$; otherwise $x(z, l)=0$. The market supply strategy for technology $z$ and market $l$ is described by the quadtuple $(x(z$, $l), i(z, l), k(z, l), s(z, l))$. The optimal value of this quadtuple is conditional on $q(z), r(z)$.

The fixed cost of undertaking $\mathrm{R} \& \mathrm{D}$ is $f(z, q(z), r(z))$; this cost encompasses all the relevant fixed costs identified in Table 1. Variable costs are expressed in terms of constant unit costs. There are seven components of variable cost (see Table 1), identified by the first argument of the cost function, $c$. The following restrictions apply:

Production costs, $c(1, z, i(z))$ depend only on technology and location of production.

Trade costs $c(2, z, l, i(z))$ depend only on technology, market and production location. Technology transfer costs $c(3, z, r(z), i(z))$ depend only on technology, R\&D location and production location. Domestic trade costs and domestic technology transfer costs are zero:

$$
\begin{array}{ll}
c(2, z, l, i(z))=0 & \text { if } i(z)=l \\
c(3, z, r(z), i(z))=0 & \text { if } i(z)=r(z)
\end{array}
$$

Licensing costs $c(4, z, q(z), k(z))$ depend only on the technology, the location of headquarters and the ownership of the product. Under internalization licensing costs are zero:

$$
c(4, z, q(z), k(z))=0 \quad \text { if } k(z)=q(z)
$$

Marketing costs $c(5, z, l, k(\mathrm{z}))$ depend only on the technology, the market and the ownership of the product. Domestic marketing costs are zero:

$$
c(5, z, l, k(\mathrm{z}))=0 \quad \text { if } k(z)=l
$$

Costs of quality control depend only on the technology, the location of production, and the ownership of the product. Subcontracting incurs a cost premium $c^{\prime}(6, z)$ that is the same at every location whoever owns the product:

$$
c(6, z, i(\mathrm{z}), k(z), 1)=c(6, z, i(\mathrm{z}), k(z), 0)+c^{\prime}(6, z)
$$


In the absence of subcontracting a domestic product-owner's quality control costs are zero:

$$
c(6, z, i(\mathrm{z}), k(z), 0)=0 \quad \text { if } k(z)=i(z)
$$

The cost of political risk depends on the technology, the location of production, the ownership of the product, and whether there is subcontracting, $c(7, z, i(z), k(z) s(z))$. Political risk can be avoided either by domestic ownership of product or by subcontracting:

$$
c(7, z, i(z), k(z) s(z))=0 \text { if either } k(z)=i(z) \text { or } s(z)=1
$$

Total unit supply costs for technology $z$ in market $l$ are

$$
c(z, q(z), r(z), l, k(z), i(z), s(z))=\Sigma_{b} c(b, z, q(z), r(z), l, k(z), i(z), s(z))(b=1, . ., 7)
$$

\section{Stage 1: Optimising supply strategy to a given market}

For given $z, q(z), r(z)$, and $l$, the objective is to minimise $c$ with respect to the location of production, $i(z, q(z), r(z), l)$, the ownership of the product, $k(z, q(z), r(z), l)$, and the subcontracting strategy, $s(z$, $q(z), r(z), l)$. Cost minimization is effected in three stages; first with respect to subcontracting, then product-ownership, and finally location of production. The variable $s$ enters only into cost components 6 and 7. To determine $s$ it is therefore sufficient to minimise the sum of components 6 and 7:

$$
\min [s] \Sigma_{b} c(b, z, q(z), r(z), l, k(z), i(z), s(z)) \quad(b=6,7)
$$

The solution gives the optimal subcontracting strategy,

$$
s^{*}=s^{*}(z, q(z), r(z), l, i(z), k(z))
$$

and the lowest cost attainable through optimal subcontracting:

$$
c^{*}(z, q(z), r(z), l, i(z), k(z))=c\left(z, q(z), r(z), l, i(z), k(z), s^{*}\right)
$$

Product-ownership, $k$, enters only into components 4-7. To determine $k$ it is therefore sufficient to minimise the sum of these components, conditional on optimal subcontracting:

$$
\min [k] \Sigma_{b} c^{*}(z, q(z), r(z), l, i(z), k(z)) \quad(b=4, . ., 7)
$$


The solution gives the optimal product-ownership strategy,

$$
k^{*}=k^{*}(z, q(z), r(z), l, i(z))
$$

and the lowest cost attainable through optimal product-ownership and subcontracting:

$$
c^{*}(z, q(z), r(z), l ; i(z))=c\left(z, q(z), r(z), l, i(z), k^{*}, s^{*}\right)
$$

Location enters into all components of cost except 4 and 5; To determine $i$ it is therefore sufficient to minimise the sum of the other components, conditional on optimal subcontracting and productownership strategies:

$$
\min [i] \Sigma_{b} c^{*}(z, q(z), r(z), l, i(z), k(z)) \quad(b=1,2,3,6,7)
$$

The solution gives the optimal location strategy,

$$
i^{*}=i^{*}(z, q(z), r(z), l)
$$

and the lowest unit cost attainable through optimal subcontracting:

$$
c^{*}(z, q(z), r(z), l)=c\left(z, q(z), r(z), l, i^{*}, k^{*}, s^{*}\right)
$$

Substituting (10) into (7) and (7) and (10) into (4) gives the optimal supply strategy for market $l$ :

$$
\begin{aligned}
& s^{*}=s^{*}(z, q(z), r(z), l) \\
& k^{*}=k^{*}(z, q(z), r(z), l) \\
& i^{*}=i^{*}(z, q(z), r(z), l)
\end{aligned}
$$

Profitability. Given $p(l), m(l)$, operating profit in market $l$ is

$$
\pi^{\prime}(z, q(z), r(z), l)=\left[p(l)-c^{*}(z, q(z), r(z), l)\right] m(l)
$$

This is the increment in technology-owner's global profit from serving market $l$ once the fixed costs of innovation have been incurred. The market will be served if and only if

$$
\pi^{\prime}(z, q(z), r(z), l)>0
$$


Let $x(z, q(z), r(z), l)$ indicate whether market entry will occur when the technology has been innovated with headquarters location $q(z)$ and R\&D location $r(z)$; then

$$
\begin{array}{ll}
x(z, q(z), r(z), l)=1 & \text { if } \pi^{\prime}(z, q(z), r(z), l)>0 \\
x(z, q(z), r(z), l)=0 & \text { if } \pi^{\prime}(z, q(z), r(z), l) \leq 0
\end{array}
$$

With efficient market supply the profit extracted from the market is therefore

$$
\pi(z, q(z), r(z), l)=\max \left[\pi^{\prime}(z, q(z), r(z), l), 0\right]
$$

The global profit from exploiting technology $z$ is the sum of the profits accruing from the individual markets, net of the fixed costs of innovation

$$
\pi^{\prime}(z, q(z), r(z))=\left[\Sigma_{l} \pi(z, q(z), r(z), l)\right]-f(z, q(z), r(z))(l=1, \ldots, N)
$$

The technology is innovated if and only if

$$
\pi^{\prime}(z, q(z), r(z))>0
$$

Let $x(z, q(z), r(z))$ indicate whether technology $z$ is innovated, conditional on $q(z), r(z)$. Then

$$
\begin{array}{ll}
x(z, q(z), r(z))=1 & \text { if } \pi^{\prime}(z, q(z), r(z))>0 \\
x(z, q(z), r(z))=0 & \text { if } \pi^{\prime}(z, q(z), r(z)) \leq 0
\end{array}
$$

The profit appropriated from innovation is therefore

$$
\pi(z, q(z), r(z))=\max \left[\pi^{\prime}(z, q(z), r(z)), 0\right]
$$

\section{Stage 2: Price determination}

Price determination is conditional on which technologies have been innovated and where their headquarters and R\&D are located. For any technology there are $Y=N^{2}+1$ possible innovation strategies, $(x(z), q(z), r(z))$, which may be indexed $y(z)=1, \ldots, Y$, where, say, $y(z)=1+x(z)(q(z)(N-1)$ $+r(z))$. In the absence of technological complementarities, each technology-owner can decide their innovation strategy independently of the others, subject only to competitive forces. Therefore $W=Y^{N}$ 
scenarios must be taken into account for price determination. These may be indexed $w=1, \ldots, W$. Let $x(z, w)=1$ if $x(z)=1$ in scenario $w$, and $x(z, w)=0$ otherwise

When a single technology has been innovated, $p(l)=v(l)$.

Consider scenarios in which two or more technologies have been innovated. From equation (12), the lowest unit cost at which market $l$ can be served using technology $z$ is $c^{*}(z, q(z), r(z), l)$. The lowest unit cost of supply under scenario $w$ is

$$
c^{+}(l, w)=\min [z \text { such that } x(z, w)=1] c^{*}(z, q(z), r(z), l)
$$

and the least cost technology is

$$
z^{+}(l) \quad=z^{+}(l, w)
$$

Let $z^{\dagger}$ be any technology under $w$ other than $z^{+}$. The second-lowest unit cost of supply under scenario $w$ is

$$
c^{++}(l, w)=\min \left[z^{\dagger} \text { such that } x\left(z^{\dagger}, w\right)=1\right] c^{*}\left(z^{\dagger}, q\left(z^{\dagger}\right), r\left(z^{\dagger}\right), l\right)
$$

Let $x(l, w)$ indicate whether or not market $l$ is supplied under scenario $w$. If $v(l) \leq c^{+}(l)$ then no profit is made and $x(l, w)=0$. Otherwise $x(l, w)=1$; price is equal to the second-least cost technology or the reservation price, whichever is the lower:

$$
p(l, w)=\min \left[c^{++}(l, w), v(l)\right]
$$

The least-cost technology-owner takes the entire local market, appropriating an operating profit

$$
\pi(l, w)=\left[p(l, w)-c^{+}(l, w)\right] m(l)
$$

Thus under scenario $w$ the profit accruing to technology $z$ is

$$
\begin{array}{rlrl}
\pi(z, l, w) & =\pi(l, w) & \text { for } z=z^{+} \text {and } v(l)>c^{+}(l) & \\
& =0 & \text { otherwise }
\end{array}
$$

Stage 3: Selection of technologies, $R \& D$ locations and headquarters locations 
The industry environment as a whole is represented by the vector of innovation decisions $\boldsymbol{y}=\{y(1), \ldots$, $y(N)\}$. The environment facing each technology-owner $z$ is described by $\boldsymbol{y}(z)=\{y(1), \ldots, y(z-1), y(z+$ $1), \ldots, y(Z)\}$. Technology-owner $z$ must optimise $y(z)$ subject to $\boldsymbol{y}(z)$.

Optimization of $y(z)$ may be effected in three stages. The first two optimise the location of headquarters and R\&D conditional on innovation, while the last optimises innovation itself. To optimise $r(z)$, determine

$$
\max [r(z)] \pi^{\prime}(z, q(z), r(z), \boldsymbol{y}(z))
$$

The solution is

$$
r^{*}(z)=r^{*}(z, q(z), \boldsymbol{y}(z))
$$

and the maximum profit is

$$
\pi^{\prime *}(z, q(z), w(z))=\pi^{\prime}\left(z, q(z), r^{*}(z), \boldsymbol{y}(z)\right)
$$

To optimise headquarters location conditional on the optimal location of $\mathrm{R} \& \mathrm{D}$,

$$
\max [r(z)] \pi^{\prime *}(z, q(z), \boldsymbol{y}(z))
$$

The solution is

$$
q^{*}(z)=q^{*}(z, \boldsymbol{y}(z))
$$

Back-substituting into (28) gives

$$
r^{*}(z)=r^{*}\left(z, q^{*}(z), \boldsymbol{y}(z)\right)=r^{*}(z, \boldsymbol{y}(z))
$$

The maximum profit attained by optimising locations is

$$
\pi^{\prime *}(z, \boldsymbol{y}(z))=\pi\left(z, q^{*}(z), r^{*}(z), \boldsymbol{y}(z)\right)
$$

The innovation indicator function is then

$$
x^{*}(z, y(z)) \quad=1 \quad \text { if } \pi *(z, y(z))>0
$$




$$
=0 \quad \text { if } \pi *(z, y(z)) \leq 0
$$

The profit generated by optimising both the innovation and the location of headquarters and R\&D is therefore

$$
\pi^{*}(z, w(z))=\max \left[\pi\left(z, q^{*}(z), r^{*}(z), \boldsymbol{y}(z)\right), 0\right]
$$

The innovation decisions of technology-owners may be taken simultaneously or sequentially. When decision-making is sequential, and the actions of followers are perfectly predictable, sub-game perfect decisions can be determined from a decision-tree. The last technology-owner in any sequence responds optimally to the commitments that the others have already made. The $Z-1^{\text {th }}$ technologyowner can predict this response from the commitments made by owners $1, \ldots, Z-2$, together with their own response. This makes his response predictable to the $Z-2^{\text {th }}$ technology-owner, and so on until the first mover is reached. This backward-recursive process determines a unique outcome.

In the case of simultaneous decisions, a solution can be found in terms of Nash equilibria. This requires that every owner's strategies be an optimal response to other owners' strategies:

$$
y^{*}(z)=y^{*}\left(z, y^{*}(1), . ., y^{*}(z-1), y^{*}(z+1), . ., y^{*}(Z)\right) \quad z=1, \ldots, Z
$$

A Nash equilibrium determines an equilibrium scenario, which may be expressed as $\boldsymbol{y}^{*}=\left(y^{*}(1), \ldots\right.$, $\left.y^{*}(Z)\right)$. A Nash equilibrium does not necessarily exist and if it exists may not be unique. 